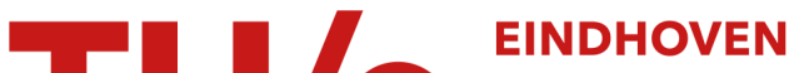 \\ UNIVERSITY OF \\ TECHNOLOGY
}

\section{The oxidative coupling of methane with cofeeding of ethane}

Citation for published version (APA):

Chen, Q., Couwenberg, P. M., \& Marin, G. B. (1994). The oxidative coupling of methane with cofeeding of ethane. Catalysis Today, 21(2-3), 309-319. https://doi.org/10.1016/0920-5861\%2894\%2980152-5, https://doi.org/10.1016/0920-5861(94)80152-5

DOI:

10.1016/0920-5861\%2894\%2980152-5

$10.1016 / 0920-5861(94) 80152-5$

Document status and date:

Published: 01/01/1994

\section{Document Version:}

Publisher's PDF, also known as Version of Record (includes final page, issue and volume numbers)

\section{Please check the document version of this publication:}

- A submitted manuscript is the version of the article upon submission and before peer-review. There can be important differences between the submitted version and the official published version of record. People interested in the research are advised to contact the author for the final version of the publication, or visit the $\mathrm{DOI}$ to the publisher's website.

- The final author version and the galley proof are versions of the publication after peer review.

- The final published version features the final layout of the paper including the volume, issue and page numbers.

Link to publication

\section{General rights}

Copyright and moral rights for the publications made accessible in the public portal are retained by the authors and/or other copyright owners and it is a condition of accessing publications that users recognise and abide by the legal requirements associated with these rights.

- Users may download and print one copy of any publication from the public portal for the purpose of private study or research.

- You may not further distribute the material or use it for any profit-making activity or commercial gain

- You may freely distribute the URL identifying the publication in the public portal.

If the publication is distributed under the terms of Article $25 \mathrm{fa}$ of the Dutch Copyright Act, indicated by the "Taverne" license above, please follow below link for the End User Agreement:

www.tue.nl/taverne

Take down policy

If you believe that this document breaches copyright please contact us at:

openaccess@tue.nl

providing details and we will investigate your claim. 


\title{
The oxidative coupling of methane with cofeeding of ethane
}

\author{
Q. Chen, P.M. Couwenberg, G.B. Marin * \\ Schuit Institute of Catalysis, Laboratorium voor Chemische Technologie, Eindhoven University of Technology, \\ P.O. Box 513, 5600 MB Eindhoven, Netherlands
}

\begin{abstract}
The oxidative coupling of methane with cofeeding of ethane was investigated experimentally both in the absence and in the presence of a $\mathrm{Sn} / \mathrm{Li} / \mathrm{MgO}$ catalyst. Cofeeding ethane in the absence of catalyst results in a higher total radical concentration, explaining the strong increase of the observed feed conversions. The hydrogen-peroxy radical-concentration increase is more pronounced than the corresponding methyl radical concentration increase, resulting in a lower selectivity. The combined effect of feed conversion and selectivity is beneficial for inlet ethane-to-methane ratios lower than $4 \mathrm{~mol} \%$. Ethane cofeeding results in a slight increase of the oxygen conversion in the presence of a $\mathrm{Sn} / \mathrm{Li}$ / $\mathrm{MgO}$ catalyst. This can be accounted for by a mechanism in which both the hydrogen abstraction from the hydrocarbon and the regeneration of the active sites are kinetically significant. The corresponding decrease of methane conversion results from competition between methane and the more reactive ethane for these sites. The addition of ethane does not result in a beneficial effect on conversions to ethane or $\mathrm{C}_{2}$.
\end{abstract}

\section{Introduction}

Ethane is a primary product in the oxidative coupling of methane and oxydehydrogenates to ethene. Consecutive total oxidation of the $\mathrm{C}_{2}$ products to $\mathrm{CO}$ and $\mathrm{CO}_{2}$ is detrimental for the selectivity. In a potential process of natural-gas upgrading through the oxidative coupling of methane, ethane may have to be fed to the reactor together with methane, because a complete separation of ethane from methane may not be economical [1]. This will be the case both for the natural-gas feed and for the recycle stream from the coupling products. Thus, the fate of ethane is important in determining the selectivity of the reaction. This topic has been addressed in the literature [1-3], but not extensively. The present work concerns a comparison of

\footnotetext{
* Corresponding author.
} 
methane coupling with cofeeding of ethane in the presence and the absence of catalyst on the basis of detailed reaction mechanisms.

\section{Experimental}

Experiments were carried out in a continuous-flow, sintered $\alpha-\mathrm{Al}_{2} \mathrm{O}_{3}$ reactor in the absence of catalyst as well as in the presence of a $\mathrm{Sn} / \mathrm{Li} / \mathrm{MgO}$ catalyst. A sintered $\alpha-\mathrm{Al}_{2} \mathrm{O}_{3}$ thermocouple well was placed in the centreline of the reactor to be able to measure the axial temperature gradient. The setup used in this study and the procedures for the experiments in the absence of catalyst have been described previously [4]. The tin-promoted lithium on magnesium oxide catalyst was prepared according to the procedure reported by Korf et al. [5]. It contains $3.5 \mathrm{wt} . \%$ $\mathrm{Li}$ and $2.6 \mathrm{wt} . \% \mathrm{Sn}$ after $50 \mathrm{ks}$ on-stream time at $1023 \mathrm{~K}$. Data reported here were all taken after $50 \mathrm{ks}$ on stream. The catalyst bed was diluted with sintered $\alpha-\mathrm{Al}_{2} \mathrm{O}_{3}$ pellets at a 10-to-1 weight ratio in order to reduce radial temperature gradients. The pellet diameter of both the catalyst and the diluent ranged from $0.21-0.30 \mathrm{~mm}$. The fixed bed was placed in the isothermal zone of a fluidized-sand oven.

The reactor, the thermocouple well and the catalyst diluent were pretreated to remove any possible contaminations. The pretreatment procedure consisted of three steps: (a) dipping the tubes in a $60 \% \mathrm{HNO}_{3}$ solution for half an hour; (b) washing the tubes with distilled water; (c) baking the tubes in an oven at $1123 \mathrm{~K}$ in air for two hours. The gases used as reactants were purchased from Hoekloos with purities of $99.995 \%$ for oxygen and methane, and $99.5 \%$ for ethane. No inert gas was used in the feed. The inlet ethane-to-methane ratio was varied from 0 to $0.10 \mathrm{~mol} \mathrm{~mol}^{-1}$. Experiments were performed in a temperature range from 973 to $1083 \mathrm{~K}$, and in a total pressure range from 100 to $400 \mathrm{kPa}$.

\section{Results and discussion}

\subsection{Conversions of methane and oxygen}

Fig. 1 shows the conversions of methane and oxygen, defined respectively as the ratio of the moles of methane or dioxygen converted to the moles of methane or dioxygen fed, as a function of the inlet ethane-to-methane molar ratio in the absence of catalyst. The inlet methane-to-oxygen ratio was kept constant at 4 .

Clearly cofecding of ethane increases largely the conversions for the oxidative coupling of methane in the absence of catalyst. Analogous experiments at $400 \mathrm{kPa}$ showed the same trend. This phenomenon is related to the branched chain nature of the reaction mechanism [6] as will be shown using the model in Table 1. This model is based on the model from Chen et al. [4] with some small modifications that allowed an adequate simulation of the experiments with cofeeding of ethane. 


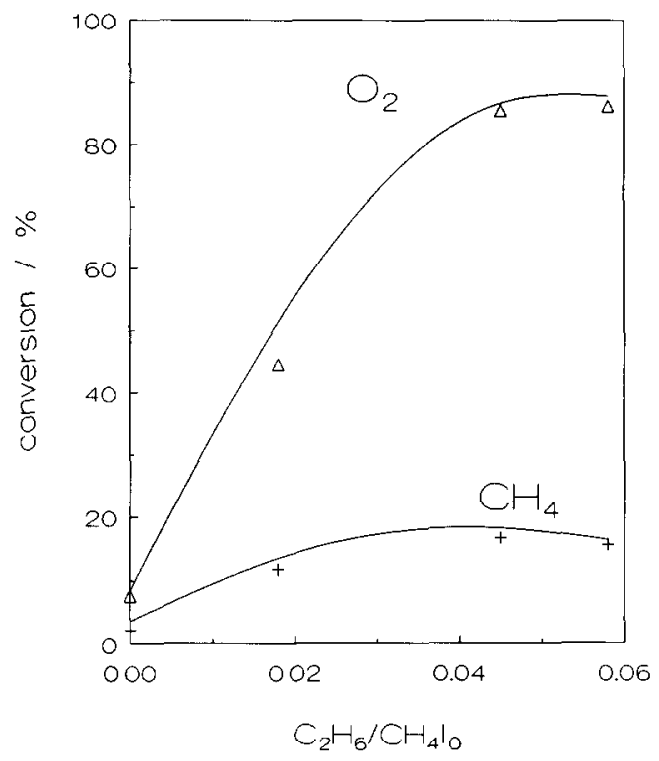

Fig. 1. Conversion of methane and oxygen versus the inlet ethane-to-methane ratio in the absence of catalyst. Full lines calculated with the model in Table 1. Points experimental. $p=100 \mathrm{kPa}, T=1083 \mathrm{~K}, V / F_{\mathrm{CH} 4,0}=0.146 \mathrm{~m}^{3}$ $\mathrm{mol} \mathrm{s}^{-1}, \mathrm{CH}_{4} / \mathrm{O}_{2} \mathrm{I}_{0}=4.0$.

It should be noted, however, that these modifications do not significantly alter the simulation results reported in [4].

In Table 2 a comparison is made between the calculated rates of branching through step 38 in Table 1, and the concentrations of the most abundant radicals in the case that no ethane was cofed and in the case that the inlet ethane-to-methane ratio was 0.05 .

Table 2 clearly shows that the ethyl-radical concentration increases by two orders of magnitude when ethane is cofed, making $\mathrm{C}_{2} \mathrm{H}_{5}$ as abundant as the two most abundant radicals in the case of feeding pure methane: $\mathrm{CH}_{3}$ and $\mathrm{HO}_{2}$. The concentrations of the latter two radicals also increase, the increase of the hydrogen-peroxy radical concentration being much more pronounced than that of the methyl radical. The strong increase in the total radical concentration is caused by the weaker $\mathrm{C}-\mathrm{H}$ bond in ethane, leading to higher propagation rates. This will be shown by comparing the rate coefficients of steps 4 and 18 in Table 1 . The dissociation energy of the $\mathrm{C}-\mathrm{H}$ bond in ethane is $411 \mathrm{~kJ} \mathrm{~mol}^{-1}$ and in methane is $440 \mathrm{~kJ} \mathrm{~mol}^{-1}$. The lower activation energy of step 18 , as is expected from the Polanyi relation [7], leads to a ratio of $k_{4} / k_{18}$ of approximately 0.1 calculated from Table 1 . This shows that a propagation step with ethane is potentially much faster than a propagation step with methane. In a branched-chain mechanism increasing propagation rates lead to higher branching rates and thus to a higher total radical concentration, as is shown in Table 2 . The rate of the branching step, which is the main radical- 
Table 1

Model for the oxidative coupling ${ }^{a}$ of methane with ethane cofeeding in the absence of catalyst

\begin{tabular}{|c|c|c|c|c|c|}
\hline No & Reaction & $\begin{array}{l}A, \mathrm{~s}^{-1} \text { or } \mathrm{m}^{3} \mathrm{~mol}^{-1} \mathrm{~s}^{-1} \text { or } \\
\mathrm{m}^{6} \mathrm{~mol}^{-2} \mathrm{~s}^{-1}\end{array}$ & $E_{\mathrm{a}}, \mathrm{kJ} \mathrm{mol}^{-1}$ & $A / R T^{\mathrm{b}}$ & $\vec{r}^{\mathbf{b}}$ \\
\hline 1 & $\mathrm{CH}_{4}+\mathrm{O}_{2} \rightleftharpoons \mathrm{CH}_{3}+\mathrm{HO}_{2}$ & $0.983 \times 10^{+07}$ & 193.86 & -2.4 & $0.10 \times 10^{+01}$ \\
\hline 2 & $\mathrm{CH}_{4}+\mathrm{H}^{\circ} \rightleftharpoons \mathrm{CH}_{3}+\mathrm{H}_{2}$ & $0.234 \times 10^{+09}$ & 51.17 & 4.1 & $0.73 \times 10^{+02}$ \\
\hline 3 & $\mathrm{CH}_{4}+\mathrm{O}^{\circ} \rightleftharpoons \mathrm{CH}_{3}^{+}+\mathrm{OH}^{\circ}$ & $0.127 \times 10^{+10}$ & 33.83 & 8.7 & $0.21 \times 10^{+01}$ \\
\hline 4 & $\mathrm{CH}_{4}+\mathrm{OH}^{*} \rightleftharpoons \mathrm{CH}_{3}^{-}+\mathrm{H}_{2} \mathrm{O}$ & $0.743 \times 10^{+09}$ & 41.43 & 7.0 & $0.12 \times 10^{+03}$ \\
\hline 5 & $\mathrm{CH}_{4}+\mathrm{HO}_{2} \rightleftharpoons \mathrm{CH}_{3}+\mathrm{H}_{2} \mathrm{O}_{2}$ & $0.401 \times 10^{+08}$ & 99.61 & 2.5 & $0.47 \times 10^{+02}$ \\
\hline 6 & $\mathrm{CH}_{3}+\mathrm{O}_{2} \rightleftharpoons \mathrm{CH}_{3} \mathrm{O}^{\circ}+\mathrm{O}^{\circ}$ & $0.308 \times 10^{+09}$ & 141.00 & 18.9 & $0.18 \times 10^{+00}$ \\
\hline 7 & $\mathrm{CH}_{3}+\mathrm{O}_{2} \rightleftharpoons \mathrm{CH}_{2} \mathrm{O}+\mathrm{OH}^{\circ}$ & $0459 \times 10^{+08}$ & 103.66 & 37.6 & $0.18 \times 10^{+01}$ \\
\hline 8 & $\mathrm{CH}_{3}^{+}+\mathrm{HO}_{2}^{-} \rightleftharpoons \mathrm{CH}_{3} \mathrm{O}^{-}+\mathrm{OH}^{-}$ & $0.885 \times 10^{+08}$ & 0.00 & 30.1 & $0.11 \times 10^{+03}$ \\
\hline 9 & $\mathrm{CH}_{3}+\mathrm{CH}_{3}+\mathrm{M} \rightleftharpoons \mathrm{C}_{2} \mathrm{H}_{6}+\mathrm{M}$ & $0.650 \times 10^{+08}$ & 000 & 3.7 & $0.16 \times 10^{+02}$ \\
\hline 10 & $\mathrm{CH}_{3} \mathrm{O}^{-}+\mathrm{M} \rightleftharpoons \mathrm{CH}_{2} \mathrm{O}+\mathrm{H}^{-}+\mathrm{M}$ & $0258 \times 10^{+15}$ & 115.00 & 3.0 & $0.12 \times 10^{+03}$ \\
\hline 11 & $\mathrm{CH}_{2} \mathrm{O}+\mathrm{OH}^{-} \rightleftharpoons \mathrm{CHO}^{+}+\mathrm{H}_{2} \mathrm{O}$ & $0.580 \times 10^{+\infty 9}$ & 5.00 & 12.9 & $0.63 \times 10^{+01}$ \\
\hline 12 & $\mathrm{CH}_{2} \mathrm{O}+\mathrm{HO}_{2} \rightleftharpoons \mathrm{CHO}^{-}+\mathrm{H}_{2} \mathrm{O}_{2}$ & $0.417 \times 10^{+07}$ & 40.12 & 8.4 & $0.46 \times 10^{+01}$ \\
\hline 13 & $\mathrm{CH}_{2} \mathrm{O}+\mathrm{CH}_{7} \rightleftharpoons \mathrm{CHO}^{-}+\mathrm{CH}_{4}$ & $0.700 \times 10^{+08}$ & 25.03 & 5.9 & $0.85 \times 10^{+02}$ \\
\hline 14 & $\mathrm{CHO}^{-}+\mathrm{M} \rightleftharpoons \mathrm{CO}+\mathrm{H}^{-}+\mathrm{M}$ & $0280 \times 10^{+10}$ & 64.36 & 8.3 & $0.87 \times 10^{+02}$ \\
\hline 15 & $\mathrm{CHO}^{-}+\mathrm{O}_{2} \rightleftharpoons \mathrm{CO}+\mathrm{HO}_{2}$ & $0.171 \times 10^{+06}$ & 0.00 & 12.9 & $0.15 \times 10^{+01}$ \\
\hline 16 & $\mathrm{CO}+\mathrm{HO}_{2} \rightleftharpoons \mathrm{CO}_{2}+\mathrm{OH}^{*}$ & $0.308 \times 10^{+69}$ & 107.34 & 40.2 & $0.27 \times 10^{+\infty}$ \\
\hline 17 & $\mathrm{C}_{2} \mathrm{H}_{6}+\mathrm{H}^{\cdot} \rightleftharpoons \mathrm{C}_{2} \mathrm{H}_{5}+\mathrm{H}_{2}$ & $0.910 \times 10^{+09}$ & 51.70 & 56 & $0.17 \times 10^{+02}$ \\
\hline 18 & $\mathrm{C}_{2} \mathrm{H}_{6}+\mathrm{OH}^{\cdot} \rightleftharpoons \mathrm{C}_{2} \mathrm{H}_{5}+\mathrm{H}_{2} \mathrm{O}$ & $0545 \times 10^{+09}$ & 17.16 & 8.4 & $0.83 \times 10^{+02}$ \\
\hline 19 & $\mathrm{C}_{2} \mathrm{H}_{6}+\mathrm{CH}_{3} \rightleftharpoons \mathrm{C}_{2} \mathrm{H}_{5}+\mathrm{CH}_{4}$ & $0.239 \times 10^{+08}$ & 64.73 & 1.4 & $0.18 \times 10^{+02}$ \\
\hline 20 & $\mathrm{C}_{2} \mathrm{H}_{5}+\mathrm{HO}_{2} \Rightarrow \mathrm{CH}_{3}^{-}+\mathrm{CH}_{2} \mathrm{O}+\mathrm{OH}^{\circ}$ & $0.948 \times 10^{+07}$ & 000 & 34.8 & $0.55 \times 10^{+01}$ \\
\hline 21 & $\mathrm{C}_{2} \mathrm{H}_{5}+\mathrm{M} \rightleftharpoons \mathrm{C}_{2} \mathrm{H}_{4}+\mathrm{H}^{\cdot}+\mathrm{M}$ & $0.596 \times 10^{+14}$ & 167.66 & 2,8 & $0.77 \times 10^{+02}$ \\
\hline 22 & $\mathrm{C}_{2} \mathrm{H}_{5}^{-}+\mathrm{O}_{2} \rightleftharpoons \mathrm{C}_{2} \mathrm{H}_{4}+\mathrm{HO}_{2}$ & $0.635 \times 10^{+07}$ & 53.20 & 7.3 & $0.32 \times 10^{+02}$ \\
\hline 23 & $\mathrm{C}_{2} \mathrm{H}_{4}+\mathrm{O}_{2} \rightleftharpoons \mathrm{C}_{2} \mathrm{H}_{3} \cdot+\mathrm{HO}_{2}$ & $0281 \times 10^{+07}$ & 14455 & 1.6 & $0.22 \times 10^{+\infty}$ \\
\hline 24 & $\mathrm{C}_{2} \mathrm{H}_{4}+\mathrm{H}^{\cdot} \rightleftharpoons \mathrm{C}_{2} \mathrm{H}_{3}+\mathrm{H}_{2}$ & $0150 \times 10^{+09}$ & 42.70 & 8.1 & $0.37 \times 10^{+00}$ \\
\hline 25 & $\mathrm{C}_{2} \mathrm{H}_{4}+\mathrm{OH}^{\prime} \rightleftharpoons \mathrm{C}_{2} \mathrm{H}_{3}+\mathrm{H}_{2} \mathrm{O}$ & $0.612 \times 10^{+08}$ & 24.70 & 11.0 & $0.19 \times 10^{+\infty}$ \\
\hline 26 & $\mathrm{C}_{2} \mathrm{H}_{4}+\mathrm{CH}_{3} \rightleftharpoons \mathrm{C}_{2} \mathrm{H}_{3}+\mathrm{CH}_{4}$ & $0199 \times 10^{+06}$ & 51.46 & 4.0 & $0.32 \times 10^{-01}$ \\
\hline 27 & $\mathrm{C}_{2} \mathrm{H}_{4}+\mathrm{OH}^{*} \rightleftharpoons \mathrm{CH}_{3}+\mathrm{CH}_{2} \mathrm{O}$ & $0.272 \times 10^{+07}$ & 0.00 & 2.0 & $0.14 \times 10^{+00}$ \\
\hline 28 & $\mathrm{C}_{2} \mathrm{H}_{3}^{\prime}+\mathrm{M} \rightleftharpoons \mathrm{C}_{2} \mathrm{H}_{2}+\mathrm{H}^{\cdot}+\mathrm{M}$ & $0.121 \times 10^{+16}$ & 176.44 & -11 & $0.19 \times 10^{.01}$ \\
\hline 29 & $\mathrm{C}_{2} \mathrm{H}_{3}+\mathrm{O}_{2} \rightleftharpoons \mathrm{C}_{2} \mathrm{H}_{2}+\mathrm{HO}_{2}$ & $0.500 \times 10^{107}$ & 0.00 & 3.5 & $0.30 \times 10^{+\infty 0}$ \\
\hline 30 & $\mathrm{C}_{2} \mathrm{H}_{3}^{-}+\mathrm{O}_{2} \rightleftharpoons \mathrm{CH}_{2} \mathrm{O}+\mathrm{CHO}^{\circ}$ & $0.550 \times 10^{+07}$ & 000 & 41.5 & $0.33 \times 10^{+\infty 0}$ \\
\hline 31 & $\mathrm{C}_{2} \mathrm{H}_{5}^{*}+\mathrm{CH}_{3}+\mathrm{M} \rightleftharpoons \mathrm{C}_{3} \mathrm{H}_{8}+\mathrm{M}$ & $0.800 \times 10^{+07}$ & 0.00 & 8.8 & $0.93 \times 10^{+00}$ \\
\hline 32 & $\mathrm{C}_{3} \mathrm{H}_{8}+\mathrm{H}^{\cdot} \rightleftharpoons \mathrm{C}_{7} \mathrm{H}_{7}^{*}+\mathrm{H}_{2}$ & $0.900 \times 10^{+09}$ & 32.00 & 5.6 & $052 \times 10^{-01}$ \\
\hline 33 & $\mathrm{C}_{2} \mathrm{H}_{4}+\mathrm{CH}_{3}+\mathrm{M} \rightleftharpoons \mathrm{C}_{3} \mathrm{H}_{7}+\mathrm{M}$ & $0.300 \times 10^{+06}$ & 29.00 & 0.6 & $0.60 \times 10^{+\infty}$ \\
\hline 34 & $\mathrm{C}_{3} \mathrm{H}_{7}+\mathrm{M} \rightleftharpoons \mathrm{C}_{3} \mathrm{H}_{6}+\mathrm{H}^{-}+\mathrm{M}$ & $0150 \times 10^{+16}$ & 156.00 & 2.1 & $0.28 \times 10^{+00}$ \\
\hline 35 & $\mathrm{O}_{2}+\mathrm{H}^{\prime} \rightleftharpoons \mathrm{OH}^{\prime}+\mathrm{O}^{\circ}$ & $0.220 \times 10^{+09}$ & 70.30 & 18.9 & $0.21 \times 10^{+01}$ \\
\hline 36 & $\mathrm{O}_{2}+\mathrm{H}^{*}+\mathrm{M} \rightleftharpoons \mathrm{HO}_{2}+\mathrm{M}$ & $0.139 \times 10^{+06}$ & 0.00 & 4.5 & $0.16 \times 10^{+113}$ \\
\hline 37 & $\mathrm{HO}_{2}^{-}+\mathrm{HO}_{2}^{-} \rightleftharpoons \mathrm{O}_{2}+\mathrm{OH}^{-}+\mathrm{OH}^{-}$ & $0.200 \times 10^{+07}$ & 0.00 & 255 & $0.13 \times 10^{+02}$ \\
\hline 38 & $\mathrm{H}_{2} \mathrm{O}_{2}+\mathrm{M} \rightleftharpoons \mathrm{OH}^{-}+\mathrm{OH}^{-}+\mathrm{M}$ & $0127 \times 10^{+12}$ & 199.36 & 20.6 & $0.30 \times 10^{+02}$ \\
\hline 39 & $\mathrm{C}_{2} \mathrm{H}_{6} \gg \mathrm{C}_{2} \mathrm{H}_{5}+\mathrm{H}^{*}$ & $0.400 \times 10^{+17}$ & 378.51 & -5.5 & $0.29 \times 10^{-01}$ \\
\hline
\end{tabular}

\footnotetext{
${ }^{a}$ Conditions $T_{\mathrm{max}}=1073 \mathrm{~K}, p_{\mathrm{t}}=400 \mathrm{kPa}, \mathrm{CH}_{4} /\left.\mathrm{O}_{2}\right|_{0}-4.75, \mathrm{C}_{2} \mathrm{H}_{6} /\left.\mathrm{CH}_{4}\right|_{0}=0.05$ and $V / F_{\mathrm{CH} / 0}=6.8 \times 10^{-4} \mathrm{~m}^{3}$ $s \mathrm{~mol}^{-1} X_{\mathrm{Cl}_{1}}=1.3 \%, X_{\mathrm{O}_{2}}=40 \%$

${ }^{\mathrm{h}} \vec{r}$ is the rate of the forward step in $\mathrm{mol} \mathrm{m}^{-3} \mathrm{~s}^{-1}$, and $A / R T$ is the dimensionless affinity [4] calculated at the point in the reactor where the temperature is maximum
} 
Table 2

Calculated rate of the branching step, step 38 in Table 1 and concentrations of the most abundant radicals in the absence of catalyst ${ }^{\mathrm{a}}$

\begin{tabular}{lllll}
\hline Feed composition & $r_{\mathrm{b}} / \mathrm{mol} \mathrm{m}^{-3} \mathrm{~s}^{-1}$ & $C_{\mathrm{HO}} / \mathrm{mol} \mathrm{m}^{-3}$ & $C_{\mathrm{CH} 3} / \mathrm{mol} \mathrm{m}^{-3}$ & $C_{\mathrm{C}_{2} \mathrm{H}_{5}} / \mathrm{mol} \mathrm{m}^{-3}$ \\
\hline $\mathrm{C}_{2} \mathrm{H}_{6} /\left.\mathrm{CH}_{4}\right|_{0}=0$ & 3.6 & $2.0 \times 10^{-4}$ & $2.7 \times 10^{-4}$ & $1.7 \times 10^{-6}$ \\
$\mathrm{C}_{2} \mathrm{H}_{6} /\left.\mathrm{CH}_{4}\right|_{0}=0.05$ & 30 & $2.5 \times 10^{-3}$ & $5.1 \times 10^{-4}$ & $2.3 \times 10^{-4}$ \\
\hline
\end{tabular}

${ }^{\mathrm{a}} \mathrm{p}=400 \mathrm{kPa}, \mathrm{T}=1073 \mathrm{~K}, \Sigma \mathrm{C} / \mathrm{O}_{2} \ell_{0}=5.0, \mathrm{X}_{\mathrm{O}_{2}}=4.0$.

producing step both with and without cofeeding ethane, is approximately 8 times faster when ethane was cofed.

For the sake of comparison, the observed hydrogen-peroxy radical concentration at $733 \mathrm{~K}$ and $100 \mathrm{kPa}$ amounted to $8 \times 10^{-6} \mathrm{~mol} \mathrm{~m}^{-3}$ in a $1: 1: 1$ mixture of $\mathrm{CH}_{4}$, Ar, $\mathrm{O}_{2}$ and to $2 \times 10^{-5} \mathrm{~mol} \mathrm{~m}^{-3}$ in a 0.5:0.5:1:1 mixture of $\mathrm{CH}_{4}, \mathrm{C}_{2} \mathrm{H}_{6}, \mathrm{Ar}$, and $\mathrm{O}_{2}$ mixture. These results were obtained by means of freezing out of radicals in combination with EPR spectroscopy [8].

In the presence of the $\mathrm{Sn} / \mathrm{Li} / \mathrm{MgO}$ catalyst much smaller effects of cofeeding ethane are observed, see Fig. 2. The oxygen conversion increases slightly, while the methane conversion even decreases. This indicates that ethane is preferentially oxidized in a methane-ethane mixture by $\mathrm{Sn} / \mathrm{Li} / \mathrm{MgO}$. This phenomenon has been reported previously [3] for a $\mathrm{SrCO}_{3} / \mathrm{La}_{2}\left(\mathrm{CO}_{3}\right)_{3}$ catalyst. During this experiment the total flow rate of methane and oxygen were kept constant at respectively $1.56 \times 10^{-4}$ and $4.00 \times 10^{-5} \mathrm{~mol} \mathrm{~s}^{-1}$, and the flow rate of ethane was varied from

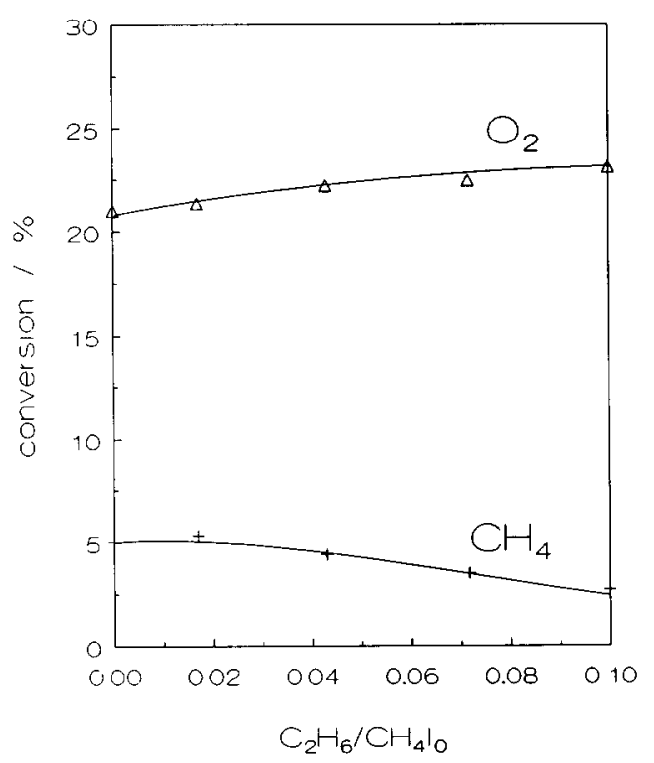

Fig. 2 Conversion of methane and oxygen versus the inlet ethane-to-methane ratio in the presence of $\mathrm{Sn} / \mathrm{Li} /$ MgO. $\mathrm{p}=125 \mathrm{kPa}, \mathrm{T}=973 \mathrm{~K}, \mathrm{CH}_{4} / \mathrm{O}_{2.0}=39, \mathrm{~W} / \mathrm{F}_{\mathrm{CH} 4.0}=2.4 \mathrm{~kg} \mathrm{~s} \mathrm{~mol}^{-1}$. 
0 to $1.56 \times 10^{-5} \mathrm{~mol} \mathrm{~s}^{-1}$. Experiments at other temperatures and inlet methane-tooxygen ratios showed a similar behaviour.

The completely different effects of ethane cofeeding in the presence and in the absence of catalyst demonstrate that the major contribution to the methane and ethane conversion in the presence of a $\mathrm{Sn} / \mathrm{Li} / \mathrm{MgO}$ catalyst results from reactions such as those shown in Eq. 1: the radical generation now occurs via a catalytic closed sequence [9]. In the first step of this sequence oxygen is dissociatively adsorbed, in the second and third step hydrogen is abstracted either from methane or from ethane to produce the radicals, and in the last step the catalyst is regenerated through water desorption.

\begin{tabular}{|c|c|c|}
\hline & & $\sigma_{1}$ \\
\hline 1.1 & $\mathrm{O}_{2}+2 * \stackrel{\mathrm{nO}}{\rightleftharpoons} 2 \mathrm{O}^{*}$ & 1 \\
\hline .2 & $\mathrm{CH}_{4}+\mathrm{O}^{*} \underset{k_{\mathrm{C}} \mathrm{H}_{6}}{\stackrel{\mathrm{C}^{2} H_{4}}{\rightarrow}} \mathrm{CH}_{3}+\mathrm{OH}^{*}$ & 4 \\
\hline .3 & $\mathrm{C}_{2} \mathrm{H}_{6}+\underset{k_{\mathrm{OH}}}{\mathrm{O}^{*}} \rightarrow \mathrm{C}_{2} \mathrm{H}_{5}+\mathrm{OH}^{*}$ & 0 \\
\hline 1.4 & $2 \mathrm{OH}^{*} \rightarrow \mathrm{H}_{2} \mathrm{O}+\mathrm{O}^{*}+*$ & 2 \\
\hline
\end{tabular}

Based on this model the observed effects of ethane addition can be explained. If it is assumed that the regeneration step, 1.4, is not a potentially infinitely fast step, and if reaction 1.1 is in equilibrium, the following relation between the fraction of frec sites on the surface, $\theta *$, and the fraction oxygen on the surface, $\theta_{\mathrm{O}^{*}}$, can be derived:

$$
\theta_{\mathrm{O}^{*}}=\sqrt{K_{\mathrm{O}_{2}} C_{\mathrm{O}_{2}}} \theta^{*}
$$

Applying the steady-state approximation to the hydroxy species yields for $\theta_{O H^{*}}$ :

$$
\theta_{\mathrm{OH}} * \sqrt{\frac{k_{\mathrm{CH}_{4}} C_{\mathrm{CH}_{4}}}{2 k_{\mathrm{OH}}}\left(1+\frac{k_{\mathrm{C}_{2} \mathrm{H}_{6}} C_{\mathrm{C}_{2} \mathrm{H}_{6}}}{k_{\mathrm{CH}_{4}} C_{\mathrm{CH}_{4}}}\right) \theta_{\mathrm{O}^{*}}}
$$

Together with the condition that the sum of the fractions of the three surface components equals 1, their values can be calculated from Eqs. 2 and 3.

To be able to calculate the effect of ethane addition on the consumption rates of methane, ethane and oxygen the relation between the rate coefficients, $k_{\mathrm{CH}_{4}}$, and $k_{\mathrm{C}_{2} \mathrm{H}_{6}}$ has to be known. The pre-exponential factor of $k_{\mathrm{C}_{2} \mathrm{H}_{6}}$ can be related to $A_{\mathrm{CH}_{4}}$ through Eq. 4 [10], which follows from the collision theory.

$$
\frac{A_{\mathrm{CH}_{4}}}{A_{\mathrm{C}_{2} \mathrm{H}_{6}}}=\frac{n_{\mathrm{H}_{1} \mathrm{CH}_{4}} \sqrt{M_{\mathrm{C}_{2} \mathrm{H}_{6}}}}{n_{\mathrm{H}, \mathrm{C}_{2} \mathrm{H}_{6}} \sqrt{M_{\mathrm{CH}_{4}}}}=0.913
$$


Table 3

Calculated ${ }^{a}$ surface coverages and calculated and experimental rate of methane consumption vs. the inlet ethaneto-methane ratio

\begin{tabular}{llllll}
\hline $\mathrm{C}_{2} \mathrm{H}_{6} /\left.\mathrm{CH}_{4}\right|_{0}$ & $\theta^{*}$ & $\theta_{\mathrm{O}^{*}}$ & $\theta_{\mathrm{OH}^{*}}$ & $R_{\mathrm{CH}, \text { calc }} / \mathrm{mol} \mathrm{kg}^{-1} \mathrm{~s}^{-1}$ & $R_{\mathrm{CH}_{+}, e x p} / \mathrm{mol} \mathrm{kg}^{-1} \mathrm{~s}^{-1}$ \\
\hline 0.0 & 0.063 & 0.0117 & 0.925 & 0.026 & 0.021 \\
0.044 & 0.052 & 0.0095 & 0.938 & 0.020 & 0.018 \\
0.100 & 0.044 & 00078 & 0.949 & 0.016 & 0.013 \\
\hline
\end{tabular}

a Values for the rate cocfficients: $k_{\mathrm{CH}_{4}}=0.20 \mathrm{~m}^{3} \mathrm{~kg}^{-1} \mathrm{~s}^{-1}, k_{\mathrm{C}_{2} \mathrm{H}_{6}}=1.40 \mathrm{~m}^{3} \mathrm{~kg}^{-1} \mathrm{~s}^{-1}, K_{\mathrm{O}_{2}}=3.8 \times 10^{-3} \mathrm{~m}^{3} \mathrm{~mol}^{-1}$, and $k_{\mathrm{OH}}=0.019 \mathrm{~mol} \mathrm{~kg}^{-1} \mathrm{~s}^{-1}$.

${ }^{\mathrm{b}}$ Conditions see Fig. 2.

As in the case of coupling in the absence of catalyst the activation energy of the hydrogen abstraction from ethane is expected to be lower than the activation energy of the hydrogen abstraction from methane due to the lower $\mathrm{C}-\mathrm{H}$ bond strength. If an activation energy difference of $15 \mathrm{~kJ} \mathrm{~mol}^{-1}$ is assumed, the ratio between $k_{\mathrm{CH}_{4}}$ and $k_{\mathrm{C}_{2} \mathrm{H}_{6}}$ amounts to 0.14 . Hence, according to Eq. 3 addition of ethane leads to an increased surface coverage by hydroxy species.

Table 3 shows the calculated surface fraction of the three surface species and the calculated and experimental rate of methane consumption versus the inlet ethaneto-methane ratio. The used values for $K_{\mathrm{O}_{2}}, k_{\mathrm{CH}_{4}}$ and $k_{\mathrm{OH}}$ were obtained from the simulation of kinetic experiments over $\mathrm{Sn} / \mathrm{Li} / \mathrm{MgO}$.

Clearly, the experimentally observed rates of methane consumption are adequately described with this model. Now this model can be used to explain the effect of ethane cofeeding. It is noted that $\theta_{\mathrm{OH}}$ * increases only from 0.925 to 0.949 with an increase of the inlet ethane-to-methane ratio from 0 to 0.10 , and thus the rate of the regeneration step rises only slightly. From the stoichiometric numbers, $\sigma$, listed in Eqs. 1 it follows that the corresponding rate of oxygen consumption is equal to one half of the rate of regeneration and that the sum of the rates of methane and ethane consumption is equal to twice that of the rate of regeneration. This explains why the oxygen consumption hardly increases with the addition of a small amount of ethane. The decreasing rate of methane consumption, viz. Table 3 and Fig. 2, follows from the decrease in $\theta_{\mathrm{O}^{*}}$. Since the sum of the rates of methane and ethane consumption increases slightly it follows that hydrogen is preferentially abstracted from ethane in an ethane-methane mixture. If the regeneration step were potentially infinitely fast, the steady-state concentration of $\mathrm{OH}^{*}$ would be zero and the corresponding concentration of $\mathrm{O}^{*}$ would only depend upon the equilibrated chemisorption of $\mathrm{O}_{2}$. The hydrogen abstraction from the hydrocarbon would then be the rate-determining step in Eqs. 1 , and $\theta_{\mathrm{O}}$ * would not be influenced by the addition of ethane. The higher rate coefficient for hydrogen abstraction from ethane would lead to a higher sum of rates of hydrogen abstraction and thus to an increasing consumption rate of oxygen. The decrease in consumption rate of methane would only be proportionally to the decrease in the methane concentration, which should be negligible. 


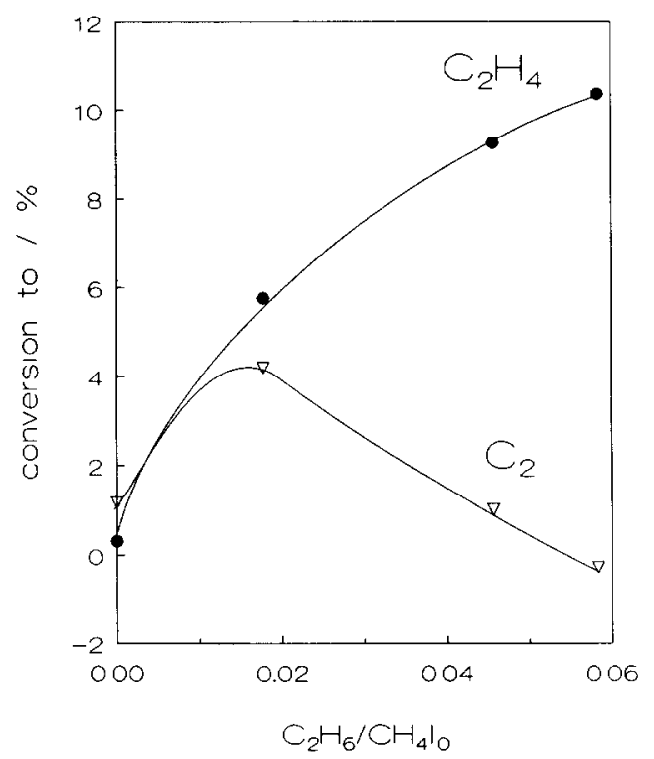

Fig. 3. Conversions to ethene and $C_{2}$ versus the inlet ethane-to-methane ratio in the absence of catalyst. Conditions see Fig. 1.

\subsection{Conversion to ethene and $C_{2}$}

Not only the effect of ethane addition on the conversion of the feed components, but also on the conversion of the latter towards ethane and ethene is important. It is convenient to use the following definitions:

$$
\begin{aligned}
& X_{\mathrm{C}_{2} \mathrm{H}_{6}}=\frac{2\left(F_{\mathrm{C}_{2} \mathrm{H}_{6}}-F_{\mathrm{C}_{2} \mathrm{H}_{6}, 0}\right)}{F_{\mathrm{CH}_{4}, 0}+2 F_{\mathrm{C}_{2} \mathrm{H}_{6}, 0}} \\
& X_{\mathrm{C}_{2} \mathrm{H}_{4}}=\frac{2 F_{\mathrm{C}_{2} \mathrm{H}_{4}}}{F_{\mathrm{CH}_{4}, 0}+2 F_{\mathrm{C}_{2} \mathrm{H}_{6}, 0}}
\end{aligned}
$$

The sum is called conversion to $\mathrm{C}_{2}$. It follows from the definitions that the conversion towards a component equals the product of the conversion of methane plus ethane and the selectivity towards that component based on the converted methane plus ethane.

Figs. 3 and 4 show some typical experimental conversions to ethene and $\mathrm{C}_{2}$ versus the inlet ethane-to-methane ratio in the absence and presence of $\mathrm{Sn} / \mathrm{Li}$ / $\mathrm{MgO}$. In the absence of catalyst the increase of the conversion into ethene with increasing inlet ethane-to-methane ratio is slightly less pronounced than the corresponding increase of the feed conversions, viz. Figs. 1 and 3, corresponding to a not completely selective conversion of ethane into ethene. It was shown previously that as much as one half of the ethane which disappears can be converted into $\mathrm{CO}$ 


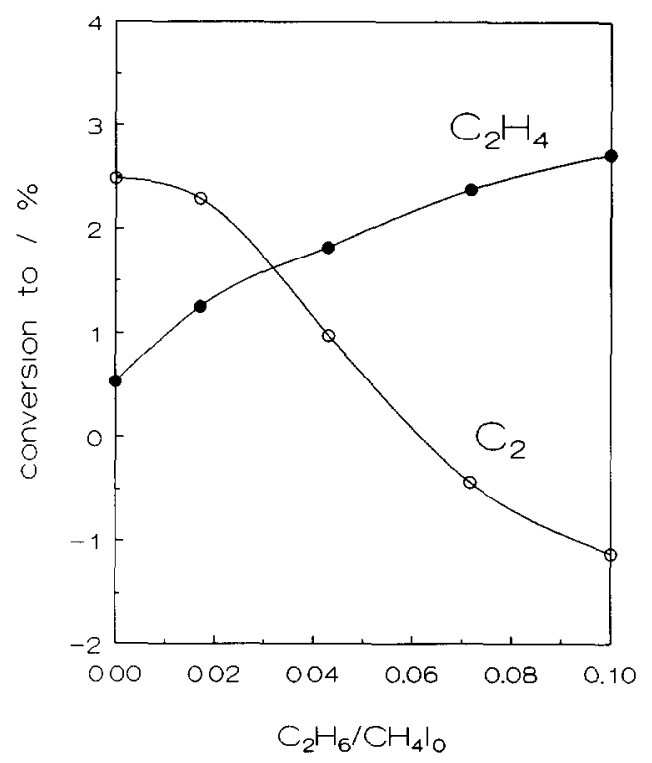

Fig. 4. Conversions to ethene and $\mathrm{C}_{2}$ versus the inlet ethane-to-methane ratio in the presence of $\mathrm{Sn} / \mathrm{Li} / \mathrm{MgO}$. Conditions see Fig. 2.

[4]. In the absence of catalyst the conversion to $C_{2}$ increases initially and then decreases to a negative value at an inlet ethane-to-methane ratio of approximately 0.05 . The initial increase of the conversion to $\mathrm{C}_{2}$ is caused by the positive effect of the addition of ethane on the conversion of methane and oxygen as explained in section 3.1. The decrease of the conversion into $\mathrm{C}_{2}$ is caused by a decrease of the selectivity with which both of the hydrocarbon feed components are converted when more ethane is added. The relevant steps are:

(8) $\mathrm{CH}_{3}+\mathrm{HO}_{2} \rightarrow \mathrm{CH}_{3} \mathrm{O}^{-}+\mathrm{OH}^{-}$

(9) $\mathrm{CH}_{3}^{+}+\mathrm{CH}_{3}^{+}+\mathrm{M} \rightarrow \mathrm{C}_{2} \mathrm{H}_{6}+\mathrm{M}$

(20) $\mathrm{C}_{2} \mathrm{H}_{5}^{+}+\mathrm{HO}_{2} \rightarrow \mathrm{CH}_{3}+\mathrm{CH}_{2} \mathrm{O}+\mathrm{OH}^{*}$

(21) $\mathrm{C}_{2} \mathrm{H}_{5}^{-}+\mathrm{M} \rightarrow \mathrm{C}_{2} \mathrm{H}_{4}+\mathrm{H}^{\cdot}+\mathrm{M}$

(22) $\mathrm{C}_{2} \mathrm{H}_{5}^{-}+\mathrm{O}_{2} \rightarrow \mathrm{C}_{2} \mathrm{H}_{4}+\mathrm{HO}_{2}^{-}$

The lower primary and secondary selectivities when cofeeding ethane are caused by the effect of ethane addition on the concentration of the most abundant radicals, see Table 2. The more pronounced increase of the concentration of the hydrogenperoxy radical causes the rate of the non-selective step 8 to increase more than the rate of the selective step 9 resulting in a lower primary selectivity. Since the concentration of the third body, $\mathrm{M}$, and dioxygen are not altered at all by the addition of ethane, the rate of non-selective step 20 increases more than the rate of the selective steps 21 and 22 explaining the lower secondary selectivity. At higher inlet ethane-to-methane ratios the negative effect of addition of ethane dominates the positive effect on the conversion of methane and oxygen. 
In the presence of $\mathrm{Sn} / \mathrm{Li} / \mathrm{MgO}$, the conversion to $\mathrm{C}_{2}$ decreases monotonically, indicating that the addition of ethane has no positive effect at all. In section 3.1 it is shown that the conversion of oxygen hardly increases, the conversion of methane decreases, and the conversion of ethane increases with the increase of ethane in the feed. The decreasing conversion of methane corresponds to a lower rate of step 1.2 resulting in a lower methyl-radical concentration and thus in a lower selectivity to ethane since the selective coupling reaction is a second order reaction with respect to the methyl radical. The combined effects of decreasing conversion of methane and the lower primary selectivity result in a lower conversion to ethane from methane. The rising conversion of ethane has a negative effect on the conversion to $\mathrm{C}_{2}$ because some of the ethane is converted into carbon oxides. Therefore the addition of ethane always has a negative influence on the conversion to $\mathrm{C}_{2}$ in the presence of a $\mathrm{Sn} / \mathrm{Li} / \mathrm{MgO}$ catalyst.

\section{Conclusions}

Cofeeding ethane increases greatly the conversions in the oxidative coupling of methane in the absence of catalyst. The lower $\mathrm{C}-\mathrm{H}$ bond energy in ethane leads to higher propagation rates when ethane is cofed, and thus to higher branching rates in a branched-chain mechanism. This results in a higher total radical concentration and thus in higher consumption rates.

Cofeeding ethane in the presence of a Sn/Li $/ \mathrm{MgO}$ catalyst led to a small increase in the conversion of oxygen and a decrease in the methane conversion. The consumption rates of methane and oxygen in the presence of catalyst are determined by a catalytic closed sequence for the production of radicals in which methane and ethane compete for the same active site. The regeneration of active sites was found to be a kinetically significant step in this sequence.

The addition of a small amount of ethane to the feed is beneficial for the production of ethene and $C_{2}$ in the absence of catalyst. When the inlet ethane-to-methane ratio exceeds 0.04 , however, the beneficial effect on the conversion to $\mathrm{C}_{2}$ disappears. With $\mathrm{Sn} / \mathrm{Li} / \mathrm{MgO}$ cofeeding of ethane has no beneficial effect at all. Thus, in a potential process for natural-gas upgrading, ethane should be separated before the stream enters the reactor. The inlet ethane-to-methane ratio allowed is 0.04 in the absence of catalyst and as little as possible in a reactor operated with $\mathrm{Sn} / \mathrm{Li} / \mathrm{MgO}$.

\section{Acknowledgements}

The financial support provided by the Commission of the European Communities in the framework of the Joule Programme under contract no. JOUF-0044-C is gratefully acknowledged. 


\section{References}

[1] J.H. Edwards, K.T Do and R.J. Tyler, in E.E. Wolf (Ed.), Methane Conversion by Oxidative Processes, Van Nostrand Reinhold, New York, 1992, p. 429.

[2] K. Asami, T. Shikada, K. Fujimoto and H. Tominaga, Ind. Eng. Chem. Res., 26 (1987) 2348.

[3] H. Mimoun, A. Robine, S. Bonnaudet and C.J. Cameron, Appl. Catal., 58 (1990) 269.

[4] Q. Chen, P.M. Couwenberg and G.B. Marin, AIChE J., 40(3) (1994) 531.

[5] S.J. Korf, J.A. Roos, L.J. Veltman, J.G. van Ommen and J.R.H. Ross, Appl. Catal., 56 ( 1989 ) 119.

[6] Q. Chen, J.H.B.J. Hoebink and G.B. Marin, Ind. Eng. Chem. Res., 30 (1991) 2091.

[7] M. Boudart and G Djéga-Mariadassou, Kinetics of Heterogeneous Catalytic Reactions, Princeton University Press, Princeton NJ, 1984, p.121.

[8] V.T. Minasyan and L.A. Vartikyan, Kinetics and Catalysis (translation of Kinet. Katal.), 32(6) (1991) 1462.

[9] T. Ito, J.-X. Wang, C.-H. Lin and J.H. Lunsford, J. Am. Chem. Soc., 107 (1985) 107.

[10M. Bistolfi, G. Fornasari, M. Molinari, S. Palmery, M. Dente and E. Ranzi, Chem. Eng. Sci., 47 (9-11) (1992) 2647. 